Selcuk Journal of Agriculture and Food Sciences

http://sjafs.selcuk.edu.tr/sjafs/index

Research Article
SJAFS

(2019) 33 (2), 99-105

e-ISSN: $2458-8377$

DOI:10.15316/SJAFS.2019.163

\title{
Influence of Mono-ammonium and Di-ammonium Phosphate on Phosphorus Use Efficiency of Maize and Bread Wheat Plants
}

\author{
Ahmed M. YOSSIF ${ }^{1, *}$, Sait GEZGIN ${ }^{1}$ \\ ${ }^{1}$ Selçuk University, Faculty of Agriculture, Department of Soil Science and Plant Nutrition, Konya, Turkey
}

\begin{tabular}{l}
\hline ARTICLE INFO \\
\hline Article history: \\
Received date: 29.04 .2019 \\
Accepted date: 09.06 .2019 \\
\hline
\end{tabular}

\section{Edited by:}

Ummuhan ÇETIN KARACA; Selçuk

University, Turkey

\section{Reviewed by:}

Ali TOPAL; Selçuk University, Turkey

Süleyman TOPAN; Ankara University,

Turkey

\section{Keywords:}

Di-ammonium Phosphate

Mono-ammonium Phosphate

Phosphorus

Maize

Wheat

\begin{abstract}
Phosphorus fixation in soils is a big problem, for that, it affects negatively on phosphorus use efficiency of the plant. The amount of phosphorus which had fixed depends on orthophosphate ions and some soil properties. The goal of two experiments [In the first maize (Zea mays L.) and the second bread wheat (Triticum aestivum L.)] to know the different influence of mono-ammonium phosphate [MAP $\mathrm{NH}_{4} \mathrm{H}_{2} \mathrm{PO}_{4}$ ] and di-ammonium phosphate [DAP $\left(\mathrm{NH}_{4}\right)_{2} \mathrm{HPO}_{4}$ ] fertilizers when were applied in the soil at rates $(0,30,60$ and 90 $\mathrm{mg} \mathrm{P}_{2} \mathrm{O}_{5} \mathrm{~kg}^{-1}$ ) on phosphorus use efficiency under greenhouse condition. Completely Randomized Design (CRD) was arranged for both experiments in four replications in first experiment and three in the second.

Results cleared that plant dry weight (PDW, $\mathrm{g} \mathrm{pot}^{-1}$ ) and plant phosphorus uptake (PPU, mg P pot ${ }^{-1}$ ) were increased with increasing doses of MAP and DAP fertilizers in both experiments according to control (0 ppm). Furthermore, apparent recovery phosphorus use efficiency (ARPUE, \%) increased in DAP at maize and decreased in MAP at wheat trial when increasing phosphorus doses. All parameters had highly significantly affected by phosphorus. Also, fertilizers were a highly significant effect on PDW, PPU and agronomic phosphorus use efficiency (APUE) in maize and PPU in the wheat trial. Otherwise, interaction $(\mathrm{F} \times \mathrm{P})$ had a highly significantly affected on PPU, physiological phosphorus use efficiency (PPUE) and ARPUE in wheat and APUE in maize. Additionally, PDW had a significant effect on interaction. When the MAP and DAP were increasing, that means increased PDW and PPU but MAP is better than DAP. Additionally, the results of the MAP in phosphorus use efficiency are better than DAP too.
\end{abstract}

\section{Introduction}

Phosphorus, nitrogen and potassium together are the most important elements as plant nutrients. Available phosphorus isn't enough in about $20 \%$ of Turkey agricultural soils (Sonmez and Ozbahce 2018). Phosphorus is primary for agriculture production, however, its use is not without entanglements. Attention to sustainable phosphorus use is no longer solely focused on reducing the detrimental environmental effect, but also explicitly linked to food and feed security (Schroder et al. 2010). Additionally, complete soil nutrients deficiency by chemical fertilization is very necessary for perfect nutrition to increase yield and decreased seed emptiness. Because soil nutrients deficiency reflected in vegetative growth and grain yield (Salvagiotti et al. 2017). Goos and Johnson (2001) stated that phosphorus fertilization very important for good establishing in spring wheat and it is very necessary for planting time

\footnotetext{
*Corresponding author email: almoatar@gmail.com
}

in spite of the soil has a high level of phosphorus. No one can deny in the soil which phosphorus defective, phosphorus fertilizers are very essential to rise yield and yield component in cereal crops (Saeed et al. 2017). In that time the weak wheat production reasons in the world are poor phosphorus use efficiency (Ali et al. 2017; Hashmi et al. 2017). Noor et al. (2017) found that when phosphorus fertilizers are applied in calcareous and basic soil the sedimentation of phosphorus by $\mathrm{Ca}^{+2}$ and $\mathrm{Mg}^{+2}$ made phosphorus use efficiency less than $25 \%$ for that the availability of phosphorus be so limited. On the other way the importance of cereal crops in the world, wheat is the first and after rice, maize is a third as food and feed crops (Amanullah et al. 2009). In that time from now up to 2030 may use a double quantity of chemical fertilizers to save person production at the same level (Gilland 1993).

Irfan et al. (2018) found that when increased phosphorus quantity $(0,30,60,120$ and $240 \mathrm{mg}$ P2O5 kg-1) so significant $(\mathrm{p}<0.05)$ increased in plant phosphorus uptake and plant dry weight and in same time was 
significant $(\mathrm{p}<0.05)$ decreased agronomic $\mathrm{P}$ efficiency (APE), Physiological P efficiency (PPE) and phosphorus recovery efficiency (PRE) of wheat plant under greenhouse condition. In greenhouse condition, increasing phosphorus doses $(0,25,50,100,150$ and 200 $\mathrm{mg} \mathrm{kg}^{-1}$ ) that is to say, increased shoot dry weight, plant phosphorus uptake and physiology phosphorus uptake efficiency of two cultivars (Pasban-90 and MH97) of bread wheat (Triticum aestivum L.) according to control (Akhtar et al. 2011). In that time, Saeed et al. (2017) stated that, in field condition in Faisalabad Pakistan in seasons 2014 and 2015 when increasing phosphorus doses $\left(0,50,100,150\right.$ and $\left.200 \mathrm{~kg} \mathrm{P} \mathrm{ha}^{-1}\right)$ in the soil, plant dry weight and grain yield of maize (Zea mays $L$.) were increased. Addition to that increasing of phosphorus amount, that means increased on agronomic phosphorus use efficiency in 2015 season. In the other direction, in field condition the yield of maize plant had no significant effect and cleared a negative affected by increasing an amount of phosphorus $(0,23$, 46, 69 and $92 \mathrm{~kg} \mathrm{P}_{2} \mathrm{O}_{5} \mathrm{ha}^{-1}$ ) when applied with planting method (1 and 2 seed hill-1) and method of phosphorus application (Spot and strip) (Mazengia 2011). KhaliliRad and Hosseini (2017) found that increased of phosphorus doses so were increased two wheat cultivars shoot dry weight. In the same way, increased the mono-ammonium phosphate (MAP) $(0,0.2,0.4$ and $0.8 \%$ ) when applied as inorganic amendments fertilizer, that is to say, increased on plant dry weight depending on control (0) (Qayyum et al. 2017). Papadopoulos (1985) found that phosphorus doses $(0,15,30$ and 35 $\mathrm{mg} \mathrm{P} \mathrm{Kg}{ }^{-1}$ ) and different phosphorus fertilizers (monoammonium phosphate, di-ammonium phosphate and superphosphate) were significantly affected $(5 \%)$ on $\mathrm{P}$ availability in calcaric soil and recovery of $\mathrm{P}(\%)$, in addition to non-significantly affected on plant dry weight of barely.

Phosphorus fixation in soils is a big problem, for that, its effect negatively on phosphorus use efficiency of the plant. The amount of phosphorus which had fixed depends on orthophosphate ions and some soil properties. The use of mono-ammonium phosphate and di-ammonium phosphate as a phosphorus chemical fertilizer is very abundant in the agriculture sector. Which one from these is good in phosphorus use efficiency of the plant. To reply to that question two trials in maize and bread wheat purpose to explain the impact of mono-ammonium phosphate and di-ammonium phosphate on phosphorus use efficiency.

\section{Materials and Methods}

Two experiments were conducted in computercontrolled research greenhouse (Temperature was $25 \pm$ $3{ }^{\circ} \mathrm{C}$, solar radiation was $1750 \pm 50 \mathrm{kcal} . \mathrm{m}^{-2}$ and rela- tive humidity was $60 \pm 10 \%$ ) of Soil Science and Plant Nutrition Department of Faculty of Agriculture, Selcuk University, Konya, Turkey. According to soil analysis, the soil which was used is poor in available phosphorus ( $\left.<8 \mathrm{mg} \mathrm{P} \mathrm{kg}^{-1}\right)$, and Sulphur (8.6 mg SO$\left.{ }_{4}^{-2} \mathrm{~kg}^{-1}\right)$, slightly alkaline ( $\mathrm{pH} 7.38)$, sandy clay loam (SCL) in texture and very poor in organic matter (Motsara and Roy, 2008). In addition to, saltless (EC $92 \mu \mathrm{S} / \mathrm{cm}$ ), very limey $(20 \%)$, insufficient nitrogen limit $\left(5.70 \mathrm{mg} \mathrm{N} \mathrm{kg}^{-}\right.$ $\left.{ }^{1}\right)$, excess $\mathrm{K}\left(290 \mathrm{mg} \mathrm{kg}^{-1}\right)$ and $\mathrm{Ca}\left(8728 \mathrm{mg} \mathrm{kg}^{-1}\right)$, sufficient in $\mathrm{Mg}$, $\left(235 \mathrm{mg} \mathrm{kg}^{-1}\right)$, Zn $\left(0.51 \mathrm{mg} \mathrm{kg}^{-1}\right), \mathrm{Mn}$ $\left.5.56 \mathrm{mg} \mathrm{kg}^{-1}\right)$ and $\mathrm{Cu}\left(1.12 \mathrm{mg} \mathrm{kg}^{-1}\right)$ and poor in Fe and $\mathrm{B}$ (2.31 and $0.45 \mathrm{mg} \mathrm{kg}^{-1}$, respectively).

The factors of two experiments composed to fertilizers $(\mathrm{F})$ as a first factor [Mono-ammonium phosphate (MAP) and Di-ammonium phosphate (DAP)] and Phosphorus (P) doses [0, 30, 60 and $90 \mathrm{mg} \mathrm{P}_{2} \mathrm{O}_{5} \mathrm{~kg}^{-1}$ ] as a second factor. The dry soil was weighted in a pot (3 kg dry by oven) and before one day of planting MAP and DAP as a chemical fertilizer were applied and mixed to the soil, then the soil was transferred to the pot again. Ammonium nitrate (AN \%33 N) as nitrogen (200 mg N kg-1) fertilization for two experiments was applied.

In addition to, two experiments, one was planted by bread wheat (Triticum aestivum L.) Bayraktar-2000 variety after vernalization for one month in three replicates $(2 \times 4 \times 3=24$ treatments $)$ and the second was planted by maize (Zea mays L.) Anti.cin 98 as popcorn variety in four replicates $(2 \times 4 \times 4=32$ treatments $)$. Two experiments were arranged in a Completely Randomized Design (CRD) in two factors. Two experiments were irrigated in the optimum stage until harvested.

Bread wheat and maize experiments were harvested after 2 and 2.5 months from planting respectively. After harvesting the samples were taken to the lab and dried in the oven in $70{ }^{\circ} \mathrm{C}$ till to stable weight and plant dry weight $\mathrm{g} / \mathrm{plot}$ (PDW) was measured. After that plant samples were ground using an electric grinder

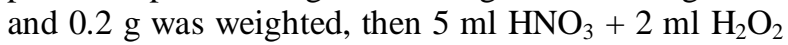
accompanied by high temperature $\left(210{ }^{\circ} \mathrm{C}\right)$ microwave device (CEM MarsXp-ress) was dissolved and the volume was completed to $20 \mathrm{ml}$, thereafter the blue band (Whatman no 42) filter paper was used for filtering. Then total $\mathrm{P}\left(\mathrm{mg} \mathrm{kg}^{-1}\right)$ was measured by ICP device and after that plant phosphorus uptake mg $\mathrm{P}$ pot $^{-1}$ was calculated. Additionally, phosphorus use efficiency (Agronomic phosphorus use efficiency (APUE), Physiology phosphorus use efficiency (PPUE) and Apparent recovery phosphorus use efficiency \% (ARPUE)) was calculated according to Noor et al. (2017) equations: 
- $(\mathrm{APUE})=$ Fertilized (Phosphorus) Biomass - Unfertilized Biomass

- $($ PPUE $)=\frac{\text { Fertilized (Phosphorus) Biomass/plot }- \text { Unfertilized Biomass } / \text { plot }}{\text { Phosphorus uptake by plant in fertilizer/plot }- \text { Phosphorus uptake by plant in unertilizer } / \text { plot }}$

- $\operatorname{ARPUE}(\%)=\frac{\text { Phosphorus uptake by plant in fertilizer } / \text { plot }- \text { Phosphorus uptake by plant in unertilizer } / \text { plot }}{\text { Amount of applied P205 }} \times 100$

All results were statistically analyzed by Computer program Minitab (Minitab 16) and mean separation

\section{Results and Discussion}

\subsection{Dry Weight and Phosphorus Uptake of Plants}

The result cleared that phosphorus doses had a highly significantly affected $(\mathrm{p}<0.01)$ on plant phosphorus uptake (PPU) and plant dry weight (PDW) in both experiments (Table 3 and 4). The similar result that, plant phosphorus uptake and biological yield ( $\mathrm{t}$ ha ${ }^{-1}$ ) of maize in 2014 and 2015 seasons had a highly significant effect $(\mathrm{p}<0.01)$ by phosphorus (Saeed et al., 2017). In the same time, Khalili-Rad and Hosseini (2017) stated, that phosphorus had a significant effect $(\mathrm{p}<0.05)$ on total phosphorus and shoot dry weight of wheat. Moreover, (Mazengia 2011) who determined that phosphorus application had a non-significant effect on biomass yield of maize as the opposite result. Also, the effect of fertilizer was highly significantly $(p<0.01)$ on PPU in two experiments and PDW in maize experiment, moreover in wheat trial fertilizer had nonsignificantly affected on PDW (Table 3 and 4). Similar results were found by Papadopoulos (1985) in calcaric soil that, different phosphorus source (monoammonium phosphate, di-ammonium phosphate and superphosphate) had a significantly affected on phosphorus availability in calcaric soil and in that time as opposite results that, different phosphorus source had a non-significantly affected on plant dry weight of barely. On the other hand, interaction $(\mathrm{F} \times \mathrm{P})$ was a highly significant effect $(p<0.01)$ on PPU in bread wheat trial and significantly affected $(\mathrm{p}<0.05)$ on PDW in maize. However, PDW in wheat and PPU in maize were nonsignificant affected by interaction (Table 3 and 4).

In these experiments while increased amount of phosphorus, PDW in maize trail at MAP in range 81 $223 \%$ in addition to at DAP in range $26-119 \%$ and in bread wheat at MAP between $20-31 \%$ in addition to at DAP between 14 - 26\% were increased depend on control $\left(0 \mathrm{mg} \mathrm{P}_{2} \mathrm{O}_{5} \mathrm{~kg}^{-1}\right)$ (Table 1). Additionally, increased phosphorus doses, PPU in maize at MAP between 58 - $164 \%$ in addition to at DAP between 54 - was performed by using LSD (Least Significant Difference) procedure.

$160 \%$ and in bread wheat at MAP in range $45-107 \%$ in addition to at DAP in range $34-210 \%$ were increased according to control (Table 1). In these researches, results explained that when applied different amount MAP $\left(\mathrm{H}_{2} \mathrm{PO}^{-}\right)$and DAP $\left(\mathrm{HPO}_{4}{ }^{\circ}\right)$ in the soil, PDW and PPU of wheat and maize had a high increased stage and MAP is better than DAP. The same results that, while increasing amount of phosphorus that means increased on barely plant dry weight at MAP between $(10-13 \%)$ in addition to at DAP in range $9-13 \%$ and the phosphorus availability in Calcaric soil at MAP $146-592 \%$ in addition to at DAP in range $115-515 \%$ according to control $\left(0 \mathrm{mg} \mathrm{kg}^{-1}\right)$ depending on control ( $0 \mathrm{mg} \mathrm{kg}^{-1}$ ) (Papadopoulos 1985). Similar result too by Khalili-Rad and Hosseini (2017) in wheat and Saeed et al. (2017) in maize were found that when was increasing phosphorus amount, that means increased on a biological yield and phosphorus uptake. Opposite results stated that increasing in phosphorus amount that means decreased a biomass yield (Mazengia 2011).

The highest dose of phosphorus (90 mg $\left.\mathrm{P}_{2} \mathrm{O}_{5} \mathrm{~kg}-1\right)$ had the largest average of PDW at MAP (27.68 g/pot) and at DAP (18.94 $\left.\mathrm{g} \mathrm{pot}^{-1}\right)$ in maize and at MAP (23.98 $\left.\mathrm{g} \mathrm{pot}^{-1}\right)$ and DAP $\left(25.19 \mathrm{~g} \mathrm{pot}^{-1}\right)$ in bread wheat (Table $1)$. In addition to the highest dose of phosphorus (90 $\mathrm{mg} \mathrm{kg}{ }^{-1}$ ) too had the largest average of PPU at MAP (24.67 $\mathrm{mg} \mathrm{P}^{\mathrm{P}}$ pot $^{-1}$ ) and at DAP (21.08 $\mathrm{mg} \mathrm{P}^{\mathrm{P}}$ pot $^{-1}$ ) in maize and at DAP (34.40 mg $\mathrm{P} \mathrm{pot}^{-1}$ ). Additionally, the largest average of PPU in bread wheat at MAP (22.47 mg $\mathrm{P}$ pot ${ }^{-1}$ ) by $60 \mathrm{mg} \mathrm{P}_{2} \mathrm{O}_{5} \mathrm{~kg}^{-1}$ dose (Table 1 ). In the other direction, the smallest mean of PDW at MAP (8.57 g/pot) and at DAP (8.65 $\left.\mathrm{g} \mathrm{pot}^{-1}\right)$ in maize farther at MAP (18.35 $\left.\mathrm{g} \mathrm{pot}^{-1}\right)$ and at DAP (20.00 $\mathrm{g} / \mathrm{pot})$ in wheat by control $\left(0 \mathrm{mg} \mathrm{P}_{2} \mathrm{O}_{5} \mathrm{~kg}^{-1}\right)$ (Table 1$)$. In addition to the smallest mean of PPU at MAP (9.35 $\mathrm{g} / \mathrm{pot})$ and at DAP (8.11 $\left.\mathrm{g} \mathrm{pot}^{-1}\right)$ in maize farther at MAP (10.85 $\left.\mathrm{g} \mathrm{pot}^{-1}\right)$ and at DAP (11.11 $\left.\mathrm{g} \mathrm{pot}^{-1}\right)$ in wheat by control $\left(0 \mathrm{mg} \mathrm{P}_{2} \mathrm{O}_{5} \mathrm{~kg}^{-1}\right)$ too (Table 1$)$. 
Table 1

Plant Dry Weight and Phosphorus Plant Uptake of Bread Wheat and Maize

\begin{tabular}{|c|c|c|c|c|c|}
\hline \multicolumn{2}{|c|}{ Treatments } & \multicolumn{2}{|c|}{ Plant Dry Wheat $\left(\mathrm{g} \mathrm{pot}^{-1}\right)$} & \multicolumn{2}{|c|}{$\begin{array}{c}\text { Phosphorus Plant Uptake (mg } \\
\left.\text { P pot }^{-1}\right)\end{array}$} \\
\hline Plants & $\begin{array}{l}\text { Phosphorus doses } \\
\left(\mathrm{mg} \mathrm{P}_{2} \mathrm{O}_{5} \mathrm{~kg}^{-1}\right)\end{array}$ & $\begin{array}{l}\text { Mono-ammonium Phos- } \\
\text { phate (MAP) }\end{array}$ & $\begin{array}{l}\text { Di-ammonium Phosphate } \\
\text { (DAP) }\end{array}$ & MAP & DAP \\
\hline \multirow{4}{*}{ Maize } & 0 & 8.57 & 8.65 & 9.35 & 8.11 \\
\hline & 30 & 15.48 & 10.88 & 14.76 & 12.50 \\
\hline & 60 & 21.60 & 13.89 & 20.38 & 15.70 \\
\hline & 90 & 27.68 & 18.94 & 24.67 & 21.08 \\
\hline \multirow{4}{*}{$\begin{array}{l}\text { Bread } \\
\text { Wheat }\end{array}$} & 0 & 18.35 & 20.00 & 10.85 & 11.11 \\
\hline & 30 & 21.93 & 22.89 & 15.69 & 14.93 \\
\hline & 60 & 23.83 & 21.93 & 22.47 & 14.61 \\
\hline & 90 & 23.98 & 25.19 & 16.89 & 34.40 \\
\hline Plants & & Maize & Bread Wheat & Maize & $\begin{array}{l}\text { Bread } \\
\text { Wheat }\end{array}$ \\
\hline \multicolumn{6}{|c|}{ Least Significant Different (LSD) } \\
\hline Fertiliz & & 1.91 & No Significant (N.S) & 1.66 & 2.18 \\
\hline LSD 5 & sphorus (P) & 2.70 & 2.58 & 2.34 & 3.08 \\
\hline LSD 5 & raction $(\mathrm{F} \times \mathrm{P})$ & 3.82 & N.S & N.S & 0.75 \\
\hline Standa & $\mathrm{F}(\mathrm{SE} \pm)$ & 0.93 & 0.88 & 0.80 & 0.75 \\
\hline $\mathrm{SE} \pm$ of & & 0.65 & 0.62 & 0.57 & 0.53 \\
\hline $\mathrm{SE} \pm$ of & on $\mathrm{F} \times \mathrm{P}$ & 1.31 & 1.25 & 1.14 & 1.06 \\
\hline
\end{tabular}

\subsection{Agronomic Phosphorus Use Efficiency, Physiol- ogy Phosphorus Use Efficiency and Apparent Re- covery Phosphorus Use Efficiency of Plants}

The result revealed that, Agronomic Phosphorus Use Efficiency (APUE), Physiology Phosphorus Use Efficiency (PPUE) and Apparent Recovery Phosphorus Use Efficiency (ARPUE) of maize and bread wheat were a highly significantly affected $(\mathrm{p}<0.01)$ by phosphorus doses (Table 3 and 4). Similar results by Irfan et al. (2018) and Akhtar et al. (2011) in wheat, Saeed et al. (2017) in maize and Papadopoulos (1985) in barely who were stated that Phosphorus had significantly affected on agronomic P efficiency (APE), Physiological P efficiency (PPE) and Phosphorus recovery efficiency (PRE). Also, the effect of fertilizer was highly significantly $(p<0.01)$ on APUE and PPUE in maize and had significantly affected $(\mathrm{p}<0.05)$ on ARPUE in bread wheat. Moreo-ver, fertilizer had nonsignificantly affected on ARPUE in maize in addition to APUE and PPUE in bread wheat trial (Table 3 and 4). Similar results were found by Papadopoulos (1985) in calcaric soil that, different phosphorus source (mono-ammonium phosphate, di-ammonium phosphate and superphos-phate) had a significantly affected $(\mathrm{p}<0.05)$ on phos-phorus recovery $(\%)$ of barley. On the other hand, interaction $(\mathrm{F} \times \mathrm{P})$ was a highly significant effect $(p<0.01)$ on APUE in popcorn and ARPUE in bread wheat. But PPUE and ARPUE in popcorn addition to APUE and PPUE bread wheat were nonsignificant affected by interaction (Table 3 and 4).

So generally, phosphorus use efficiency (APUE, PPUE and ARPUE) of wheat and maize in MAP application is higher than DAP application. Papadopoulos (1985) who found that phosphorus recovery (\%) of barely in MAP is better than DAP. In addition to, while increased amount of phosphorus that means APUE at DAP in range $12-53 \%$ and ARPUE at DAP too between $7-21 \%$ in maize trail were increased moreover, APUE in bread wheat at MAP between $23-48 \%$ in addition to at DAP in range $40-67 \%$ were decreased according to the small-est quantity of phosphorus (30 mg kg-1) (Table 2). The same result to maize and in that time opposite result for bread wheat was found by Saeed et al. (2017) who stated while phosphorus doses were in-creasing that means increased agronomic efficiency of maize. Moreover, the opposite result for maize and the same result for wheat that, increased of phosphorus quantity, decreased of Agronomic P efficiency (APE) of the wheat plant depending on the lowest amount of phosphorus (Irfan et al. 2018). Furthermore, PPUE in corn at MAP in range $8-10 \%$ also, in wheat at MAP between $13-42 \%$ in addition to at DAP in range $38-69 \%$ were decreased depending on the smallest quantity of phosphorus (30 mg P2O5 kg-1) (Table 2). Similar result found that increased in phosphorus amount, that means decreased in phosphorus physiological efficiency of maize (Saeed et al. 2017). As an opposite result, an increased amount of phosphorus that is to say physiology phosphorus use efficiency of wheat was increased (Akhtar et al. 2011). Also when phosphorus was ascending, ARPUE in maize at DAP between $7-21 \%$ were increased moreover in wheat at MAP in range 50 - 38\% was decreased depending on the smallest amount of phosphorus (30 mg P2O5 kg-1) (Table 2). Similar result for wheat and the opposite result for maize was found by Papadopoulos (1985) stated that, increasing amount of phosphorus that means decreased phosphorus recovery $(\%)$ of barely at MAP between $62-47 \%$ and at DAP 56 - $65 \%$ accord- 
ing to the smallest quantity of phosphorus $(15 \mathrm{mg} \mathrm{P} \mathrm{kg-}$ 1).

The highest mean of APUE of maize at MAP was $60 \mathrm{mg}$ P2O5 kg-1 dose (80.55) and at DAP was $90 \mathrm{mg}$ $\mathrm{P} 2 \mathrm{O} 5 \mathrm{~kg}-1$ dose (45.06) and of wheat was $30 \mathrm{mg}$ P2O5 $\mathrm{kg}-1$ dose (39.74) and (32.11) at MAP and DAP respectively (Table 2). Also, the highest mean of PPUE of maize was $90 \mathrm{mg}$ P2O5 kg-1 dose (555) and (338) at MAP and DAP respectively in addition to of wheat was $30 \mathrm{mg}$ P2O5 kg-1 dose (356) and (343) at MAP and DAP respectively too (Table 2). Furthermore, the highest mean of ARPUE of maize at MAP was $60 \mathrm{mg}$ P2O5 kg-1 (14.04\%) and at DAP $90 \mathrm{mg}$ P2O5 kg-1 dose $(11.00 \%)$ and of wheat at MAP was $30 \mathrm{mg}$ P2O5 $\mathrm{kg}-1$ dose $(14.32 \%)$ and at DAP $90 \mathrm{mg}$ P2O5 kg-1 dose $(18.36 \%)$ (Table 2). In other direction, the smallest mean of APUE of maize at MAP was $90 \mathrm{mg}$ P2O5 kg1 dose (70.78) and at DAP was $30 \mathrm{mg}$ P2O5 kg-1 dose (29.50) and of wheat at MAP was $90 \mathrm{mg}$ P2O5 kg-1 dose (20.85) and DAP was $60 \mathrm{mg}$ P2O5 kg-1 dose (10.74) (Table 2). Additionally, the smallest mean of PPUE of maize at MAP was $30 \mathrm{mg}$ P2O5 kg-1 dose (504) and at DAP $60 \mathrm{mg}$ P2O5 kg-1 dose (299) in addition to, of wheat at MAP was $60 \mathrm{mg} \mathrm{P} 2 \mathrm{O} 5 \mathrm{~kg}-1$ dose (206) and at DAP was $90 \mathrm{mg}$ P2O5 kg-1 dose (108) (Table 2). In addition to, the smallest mean of ARPUE of maize at MAP was $90 \mathrm{mg}$ P2O5 kg-1 (9.36\%) and at DAP $30 \mathrm{mg}$ P2O5 kg-1 dose (9.06\%) and of wheat at MAP was $60 \mathrm{mg}$ P2O5 kg-1 dose $(5.16 \%)$ and $(4.95 \%)$ at MAP and DAP respectively (Table 2).

Table 2

Phosphorus Use efficiency of Bread Wheat and Maize

\begin{tabular}{|c|c|c|c|c|c|c|c|}
\hline \multicolumn{2}{|c|}{ Treatments } & \multicolumn{2}{|c|}{$\begin{array}{l}\text { Agronomic Phosphorus (P) Use } \\
\text { Efficiency }\end{array}$} & \multicolumn{2}{|c|}{$\begin{array}{l}\text { Physiology P Use } \\
\text { Efficiency }\end{array}$} & \multicolumn{2}{|c|}{$\begin{array}{c}\text { Apparent } \\
\text { Recovery P } \\
\text { Efficiency }(\%)\end{array}$} \\
\hline Plants & $\begin{array}{c}\text { Phosphorus } \\
\text { doses } \\
\text { (mg P2O5 kg-1) }\end{array}$ & $\begin{array}{l}\text { Mono-ammonium Phos- } \\
\text { phate (MAP) }\end{array}$ & $\begin{array}{l}\text { Di-ammonium Phosphate } \\
\text { (DAP) }\end{array}$ & MAP & DAP & MAP & DAP \\
\hline \multirow{4}{*}{ Maize } & 0 & 0.00 & 0.00 & 0 & 0 & 0.00 & 0.00 \\
\hline & 30 & 76.83 & 29.50 & 504 & 312 & 13.77 & 9.06 \\
\hline & 60 & 80.55 & 33.06 & 546 & 299 & 14.04 & 9.66 \\
\hline & 90 & 70.78 & 45.06 & 555 & 338 & 9.36 & 11.00 \\
\hline \multirow{4}{*}{$\begin{array}{l}\text { Bread } \\
\text { Wheat }\end{array}$} & 0 & 0.00 & 0.00 & 0 & 0 & 0.00 & 0.00 \\
\hline & 30 & 39.74 & 32.11 & 356 & 349 & 10.32 & 9.70 \\
\hline & 60 & 30.42 & 10.74 & 206 & 218 & 5.16 & 4.45 \\
\hline & 90 & 20.85 & 19.20 & 308 & 108 & 6.49 & 18.36 \\
\hline \multicolumn{2}{|l|}{ Plants } & Maize & Bread Wheat & Maize & $\begin{array}{c}\text { Bread } \\
\text { Whea } \\
\mathrm{t}\end{array}$ & $\begin{array}{c}\text { Maiz } \\
\text { e }\end{array}$ & $\begin{array}{c}\text { Bread } \\
\text { Whea } \\
\mathrm{t}\end{array}$ \\
\hline \multicolumn{2}{|c|}{$\begin{array}{l}\text { Least Significant Different } \\
\text { (LSD) Fertilizers (F) } 5 \%\end{array}$} & 7.70 & No Significant (N.S) & 117 & N.S & N.S & 2.35 \\
\hline \multicolumn{2}{|c|}{ LSD 5\% of Phosphorus (P) } & 10.90 & 14.19 & 166 & 94 & 3.64 & 3.32 \\
\hline \multicolumn{2}{|c|}{ LSD $5 \%$ of interaction $(\mathrm{F} \times \mathrm{P})$} & 15.41 & N.S & N.S & N.S & N.S & 4.70 \\
\hline \multicolumn{2}{|c|}{ Standard Error of $\mathrm{F}(\mathrm{SE} \pm$ ) } & 3.73 & 4.86 & 57 & 32 & 1.25 & 1.14 \\
\hline \multicolumn{2}{|c|}{$\mathrm{SE} \pm$ of $\mathrm{P}$} & 2.64 & 3.44 & 40 & 23 & 0.88 & 0.80 \\
\hline \multicolumn{2}{|c|}{$\mathrm{SE} \pm$ of interaction $\mathrm{F} \times \mathrm{P}$} & 5.28 & 6.87 & 80 & 45 & 1.76 & 1.61 \\
\hline
\end{tabular}

\section{Conclusions}

Phosphorus use efficiency of calcareous soil is very low. So increase of plant phosphorus use efficiency, that means decreased the use of phosphorus fertilizers. In these researches, while MAP and DAP fertilizers doses were increasing, highly significantly increased on PDW and PPU according to $0 \mathrm{mg}$ P2O5 kg-1 dose, but MAP was better than DAP. Generally, while MAP and DAP fertilizers doses were increasing, at DAP
APUE and ARPUE of popcorn were increased moreover, in bread wheat plant APUE at MAP and DAP in addition to, ARPUE at MAP were decreased and general MAP was better than DAP too. Also, when MAP and DAP fertilizers doses were increasing, that means in popcorn at MAP and in bread wheat at MAP and DAP PPUE was decreased and generally MAP was better than DAP too. Finally, when increased phosphorus doses, phosphorus use efficiency was decreased and MAP was better than DAP generally. 
Table 3

Variance analysis of parameters of maize

\begin{tabular}{lcccccc}
\hline & & \multicolumn{5}{c}{ Mean square } \\
\cline { 5 - 7 } Treatments & $\begin{array}{c}\text { Degree } \\
\text { Freedom }\end{array}$ & $\begin{array}{c}\text { Plant Dry } \\
\text { Weight }\end{array}$ & $\begin{array}{c}\text { Plant } \\
\text { Phosphorus } \\
\text { Uptake }\end{array}$ & $\begin{array}{c}\text { Agronomic } \\
\text { phosphorus } \\
\text { use efficiency }\end{array}$ & $\begin{array}{c}\text { Physiology } \\
\text { phosphorus use } \\
\text { efficiency }\end{array}$ & $\begin{array}{c}\text { Apparent recovery } \\
\text { phosphorus use } \\
\text { efficiency }\end{array}$ \\
\hline Fertilizers (F) & 1 & $219.713^{* *}$ & $69.205^{* *}$ & $7265.287 * *$ & $215804.30^{* *}$ & $27.739 \mathrm{NS}$ \\
Phosphorus (P) & 3 & $316.518^{* *}$ & $292.684^{* *}$ & $6296.885^{* *}$ & $364525.14^{* *}$ & $252.512^{* *}$ \\
F×P interaction & 3 & $31.368^{*}$ & $4.556 \mathrm{NS}$ & $1016.585^{* *}$ & $24974.27 \mathrm{NS}$ & $20.091 \mathrm{NS}$ \\
Error & 24 & 6.864 & 5.154 & 111.484 & 25904.38 & 12.434 \\
Total & 31 & - & - & - & - & - \\
\hline
\end{tabular}

(**) Highly significantly affected (1\%), (*) Significantly affected (5\%), (N.S) non-significantly affected

Table 4

Variance analysis of parameters of bread wheat

\begin{tabular}{lcccccc}
\hline & & \multicolumn{5}{c}{ Mean square } \\
\cline { 3 - 7 } Treatments & $\begin{array}{c}\text { Degree } \\
\text { Freedom }\end{array}$ & $\begin{array}{c}\text { Plant Dry } \\
\text { Weight }\end{array}$ & $\begin{array}{c}\text { Plant Phospho- } \\
\text { rus Uptake }\end{array}$ & $\begin{array}{c}\text { Agronomic phos- } \\
\text { phorus use efficien- } \\
\text { cy }\end{array}$ & $\begin{array}{c}\text { Physiology } \\
\text { phosphorus } \\
\text { use efficiency }\end{array}$ & $\begin{array}{c}\text { Apparent recov- } \\
\text { ery phosphorus } \\
\text { use efficiency }\end{array}$ \\
\hline Fertilizers (PF) & 1 & $1.392 \mathrm{NS}$ & $31.271^{* *}$ & $314.369 \mathrm{NS}$ & $\begin{array}{c}14220.150 \\
\text { NS }\end{array}$ & $41.627^{*}$ \\
Phosphorus (P) & 3 & $30.633^{* *}$ & $229.228^{* *}$ & $1301.929 * *$ & $\begin{array}{c}126798.422^{* *} \\
15220.008\end{array}$ & $184.370^{* *}$ \\
F×P interaction & 3 & $3.876 \mathrm{NS}$ & $174.178^{* *}$ & $119.245 \mathrm{NS}$ & $\mathrm{NS}$ & $56.919 * *$ \\
Error & 16 & 4.687 & 3.343 & 141.753 & 6208.853 & 7.770 \\
Total & 23 & - & - & - & - & - \\
\hline
\end{tabular}

\section{Acknowledgments:}

I need to give thanks to the Scientific Research Projects (BAP) of Selcuk University for financial support and my staff and colleagues of Soil Science and Plant Nutrition Department to support me to complete this work. Additionally, I would like to thank the Ministry of Agriculture, Livestock and Irrigation, Khartoum State in my country Sudan and Turkey Scholarship for their unwavering support.

\section{References:}

Akhtar M,Tahir S, Ashraf MY, Akhter J, Alam SM (2011). Influence of Different Rates of Phosphorus on Growth, Yield and Phosphorus Use Efficiency in Two Wheat Cultivars. Journal of Plant Nutrition, 34(8), 1223-1235.

Ali I, Mustafa A, Yaseen M, Imran M (2017). Polymer coated DAP helps in enhancing growth, yield and phosphorus use efficiency of wheat (Triticum aestivum L.). Journal of Plant Nutrition, 40(18), 2587-2594.

Amanullah, Khattak RA, Khalil SK (2009). Plant density and nitrogen effects on maize phenology and grain yield. Journal of Plant Nutrition, 32(2), 246-260.

Gilland B (1993). Cereals, nitrogen and population: an assessment of the global trends. Endeavour, 17(2), 84-88.
Goos RJ, Johnson BE (2001). Response of spring wheat to phosphorus and sulphur starter fertilizers of differing acidification potential. Journal of Agricultural Science, 136, 283-289.

Hashmi ZU, Khan MJ, Akhtar M, Sarwar T, Khan MJ (2017). Enhancing phosphorus uptake and yield of wheat with phosphoric acid application in calcareous soil. Journal of the Science of Food and Agriculture, 97(6), 1733-1739.

Irfan M, Abbas M, Shah JA, Memon MY (2018). Internal and External Phosphorus Requirements for Optimum Grain Yield are Associated with Putilization Efficiency of Wheat Cultivars. Communications in Soil Science and Plant Analysis, 1-11.

Khalili-Rad R, Hosseini HM (2017). Assessing the Effect of Phosphorus Fertilizer Levels on Soil Phosphorus Fractionation in Rhizosphere and NonRhizosphere Soils of Wheat. Communications in Soil Science and Plant Analysis, 48(16), 19311942.

Mazengia W (2011). Effects of methods and rates of phosphorus fertilizer application and planting methods on yield and related traits of maize (Zea mays L.) on soil of hawassa area. Innov. Syst. Des. Eng, 12, 315-335.

Motsara M, Roy RN (2008). Guide to laboratory establishment for plant nutrient analysis (Vol. 19): 
Food and Agriculture Organization of the United Nations Rome.

Noor S, Yaseen M, Naveed M, Ahmad R (2017). Effectiveness of Diammonium Phosphate Impregnated with Pseudomonas Putida for Improving Maize Growth and Phosphorus Use Efficiency. JAPS, Journal of Animal and Plant Sciences, 27(5), 1588-1595.

Papadopoulos I (1985). Monoammonium and Diammonium Phosphates and Triple Superphosphate as Sources of $\mathrm{P}$ in a Calcareous Soil. Fertilizer Research, 6(2), 189-192.

Qayyum MF, Rehman MZU, Ali S, Rizwan M, Naeem A, Maqsood MA, Khalid H, Rinklebe J, Ok YS (2017). Residual effects of monoammonium phosphate, gypsum and elemental sulfur on cadmium phytoavailability and translocation from soil to wheat in an effluent irrigated field. Chemosphere, 174, 515-523.

Saeed MT, Wahid MA, Saleem MF, Aziz T (2017). Enhancing Phosphorus use Efficiency by
Supplementing through Soil Applications and Seed Phosphorus Reserves in Maize (Zea mays). International Journal of Agriculture and Biology, 19(6), 1394-1400.

Salvagiotti F, Prystup P, Ferraris G, Couretot L, Magnano L, Dignani DB, Gutierrez-Boemoem FHG (2017). N:P:S stoichiometry in grains and physiological attributes associated with grain yield in maize as affected by phosphorus and sulfur nutrition. Field Crops Research, 203, 128-138. doi:10.1016/j.fcr.2016.12.019

Schroder J, Cordell D, Smit A, Rosemarin A (2010). Sustainable use of phosphorus: EU tender ENV. B1/ETU/2009/0025. Retrieved from

Sonmez B, Ozbahce A (2018). Turkey Soils Productivity and Some Organic Carbon (TOC), Creating by Content of Geographical Database. Retrieved from Ankara. 